\title{
ARE CDX2, BETA-CATENIN AND WNT IMMUNOMARCHERS USEFUL FOR EVALUATING THE CHANCE OF DISEASE PROGRESSION OR EVOLUTION TO DEATH IN PATIENTS WITH COLORECTAL CANCER?
}

\author{
Os imunomarcadores CDX2, beta-catenina e WNT são úteis para avaliar a chance de progressão de doença \\ ou a evolução para óbito em pacientes com câncer colorretal?
}

\author{
Fabiola Pabst BREMER ${ }^{1,2 \odot}$, Nicolau Gregori CZECZKO ${ }^{1 \oplus}$, Luiz Martins COLLAÇO $^{1 \oplus}$, Letícia Elizabeth \\ Augustin Czeczko RUTZ ${ }^{\oplus}$, Guilherme GIONEDIS $^{1 \oplus}$, Camila Kienen YAMAKAWA ${ }^{1 \oplus}$
}

\begin{abstract}
Background: Colorectal cancer (CRC) is one of the most common types of cancer in the world. Over time, intestinal epithelial cells undergo mutations that may lead to proliferative advantage and the emergence of cancer. Mutations in the beta-catenin pathway are amongst those described in the development of CRC. Aim: To verify the existence of a relation between the presence of Wnt3, beta-catenin and CDX2 in colorectal cancer samples and clinical outcomes such as disease progression or death. Method: Wnt3a beta-catenin and CDX2 immunohistochemistry was performed on CRC tissue microarray samples $(n=122)$, and analysis regarding the relation between biomarker expression and disease progression or death was performed. Results: No significant difference was found between the presence or absence of CDX2, beta-catenin or Wnt3a expression and clinical stage, tumor grade, disease progression or death. Conclusion: CDX2, beta-catenin and Wnt3a are not useful to predict prognosis in patients with CRC.

HEADINGS: CDX2. Beta-catenin. Wnt3. Colorectal cancer.
\end{abstract}

RESUMO - Racional: O câncer colorretal (CCR) é um dos tipos mais comuns no mundo. As células epiteliais intestinais podem sofrer mutações que ocasionam vantagem proliferativa e culminam com o surgimento do câncer. Mutações da via da beta-catenina foram descritas entre as que podem ocasioná-lo. Objetivo: Verificar a existência de relação entre a expressão de Wnt3, beta-catenina e CDX2 em amostras de câncer colorretal com os eventos clínicos progressão de doença e óbito. Método: Foi realizada análise imunoistoquímica de Wnt3a, beta-catenina e CDX2 em blocos multiamostrais de CRC $(n=122)$, e avaliada a relação entre a expressão dos biomarcadores e os desfechos progressão de doença e óbito. Resultados: Não foram encontradas diferenças significativas entre a expressão ou ausência de CDX2, beta-catenina ou Wnt3a e estádio clínico, grau de diferenciação tumoral, presença de progressão de doença ou evolução ao óbito. Conclusão: Os marcadores CDX2, betacatenina e Wnt3a não são úteis para predizer prognóstico em pacientes com CCR.

DESCRITORES - CDX2. Beta-catenina. Wnt3. Câncer colorretal.

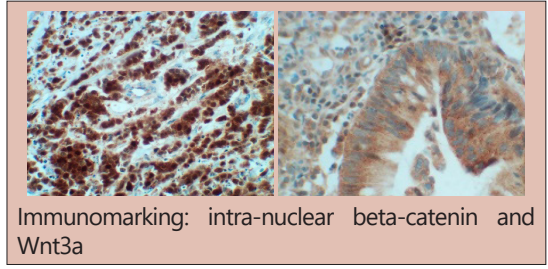

\section{Central message}

The tumor markers CDX2, beta-catenin and Wnt3a are not good prognostic predictors in patients with colorectal cancer.

\begin{tabular}{|l|}
\hline Perspectie \\
Contrary to recent literature, this immunoanalytical \\
study shows low applicability of tumor markers \\
CDX2, beta-catenin and Wnt3a in predicting clinical \\
outcomes such as disease progression or evolution \\
to death in the context of colorectal cancer.
\end{tabular}

How to cite this article: Bremer FP, Czeczko NG, Collaço LM, Rutz LEAC, Gionedis G, Yamakawa CK. Are CDX2, beta-catenin and WNT immunomarchers useful for evaluating the chance of disease progression or evolution to death in patients with colorectal cancer? ABCD Arq Bras Cir Dig. 2020;33(3):e1534. DOI: /10.1590/0102-672020200003e1534

Correspondence

Fabiola Pabst Bremer

E-mail: fabiolabremer@outlook.com
Financial source: This study was financed in part by the Coordenação de Aperfeiçoamento de Pessoal de Nível Superior - Brasil (CAPES) - Finance Code 001

Conflict of interest: none

Received for publication: 15/04/2020

Accepted for publication: 03/07/2020 
INTRODUCTION

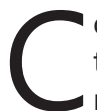
olorectal cancer (CRC) is the third most common type of cancer in the world, being the third most common in men in Brazil and the second in women ${ }^{13}$. Annually, more than one million diagnoses are performed worldwide, with an estimated mortality of 600,000 individuals per year ${ }^{23}$. In Brazil alone, it is estimated that there will be 20,520 new cases in men and 20,470 in women for each year of the 2020-2022 period. Five-year survival is directly related to staging ${ }^{9}$, and varies from $90 \%$, if localized disease, to $14 \%$ in the presence of metastasis ${ }^{12,22}$

The development of CRC begins with the occurrence of mutations in the cells of the intestinal epithelium, which cause proliferative advantages ${ }^{10}$. The increased proliferation leads to the formation of benign adenomatous polyps, which can progress to the genesis of malignant tumors ${ }^{10}$. The time between adenoma and cancer development is about 10 years ${ }^{5}$. Several mutations have already been related to the development of colorectal cancer, including those of the APC genes (adenomatous polyposis coli), KRAS, p53, of the beta-catenin gene, among others ${ }^{5}$.

Wnt proteins are glycoproteins that control cell development, proliferation and death from activation of the Wnt/beta-catenin pathway ${ }^{25}$. In this way, the proteins Wnt1, Wnt3a and Wnt7a would stimulate the inactivation of the formation of the beta-catenin destruction complex (formed by casein kinase 1 - CK1, glycogen synthase kinase 3 - GSK3, axin protein and APC protein), causing intracellular accumulation of beta-catenin ${ }^{21}$. This accumulation leads to the activation of target genes of the Wnt/beta-catenin pathway, responsible for controlling cell proliferation. When this pathway is deregulated, either by hyperstimulation by Wnt or by other mutations that lead to an increase in free intracellular beta-catenin, marked cell proliferation is generated, which can originate $C R C^{25}$.

The CDX2 transcription factor (caudal type homeobox type 2) is part of the set of proteins encoded by the genes of the homeobox group, which are responsible for the formation of factors essential to the initial development of the embryo, as well as standardization and cell identification? After birth, CDX2 expression becomes important for the morphogenesis of the intestinal epithelium, where it remains present throughout life $\mathrm{e}^{4}$; therefore, it can be used as a specific marker of colorectal tissue in immunohistochemical studies ${ }^{16}$.

It is believed that, in addition to defining the intestinal phenotype in epithelial cells, CDX2 also has a tumor suppression function ${ }^{6}$, since its absence correlates with less histological differentiation and advanced staging in colorectal malignant tumors ${ }^{3,20}$. The mechanism of this suppression is not fully understood, but it is believed that the CDX2 transcription factor acts by blocking the Wnt/beta-catenin signaling pathway ${ }^{12}$.

This research aimed to relate the immunostaining of colorectal cancer samples for CDX2, beta-catenin and Wnt3a with the presence of disease progression and evolution to death.

METHOD

This study was approved by the Research Ethics Committee of Mackenzie Evangelical Faculty of Paraná, Curitiba, PR, Brazil under no. 1,999,670.

Retrospectively, 122 patients with a diagnosis of colorectal adenocarcinoma performed between the years 2010 and 2015 at the University Evangelical Mackenzie Hospital, Curitiba, $\mathrm{PR}$, Brazil, were included. The tissue samples from these patients were separated in the hospital's pathology laboratory and sent for immunostaining. For immunohistochemical evaluation, multi-sample blocks were made using the Tissue Tek Quick-Array ${ }^{\top M}$ handpiece, which uses clamps coupled with diameters of 1-3 $\mathrm{mm}$ to extract the registered area.

The multi-sample blocks allowed up to 60 fragments of the tumor tissues to be obtained, being subsequently processed and submitted to the immunoperoxidase technique, performed by the Benchmark Ultra ${ }^{\mathrm{TM}}$ instrument. The readings were taken after amplification of the label by the primary antibodies, by two pathologists at different times. The results were classified as positive (in the presence of marking), negative (in the absence of marking) or indeterminate. The following clones were used for marking: CDX-2 clone EPR2764Y, manufactured by Cell Marque; beta-catenin clone 14, manufactured by Ventana; and polyclonal Wnt3a, manufactured by Genetex.

Data collection was carried out between March and July 2018 , through the analysis of physical and electronic medical records, pathological anatomy reports, image exams and reports for requesting high-cost procedures (chemotherapy).

\section{Statistical analysis}

The results of the quantitative variables were described by means, standard deviations, median and minimum and maximum values. Categorical variables were described by frequencies and percentages. Fine and Gray models were adjusted for the analysis of factors associated with the time until disease progression (PEVENT), considering death as a competitive risk. After adjustment, the estimated association measure was the subdistribution hazard ratio (SHR). For the survival analysis, Cox regression models were adjusted and the hazard ratio values were estimated. For both models, the Wald test was used to assess the significance of the variables. Values of $p<0.05$ indicated statistical significance. The data were analyzed using the computer program Stata/ SE v.14.1, Stata Corp LP, USA.

\section{RESULTS}

Of the 122 patients, 63 were men (51.6\%) and 59 women (48.4\%). Most cases were between $50-70$ years old at the time of diagnosis ( $n=69,56.6 \%)$; the most common degree of histological differentiation was moderately differentiated ( $n=101,82.8 \%$ ). Most cases had advanced staging at the time of diagnosis (UICC III and IV, $\mathrm{n}=74,60.7 \%$, Table 1).

TABLE 1 - Epidemiological data $(n=122)$

\begin{tabular}{|c|c|c|}
\hline & $\mathrm{n}$ & $\%$ \\
\hline \multicolumn{3}{|l|}{ Age at diagnosis } \\
\hline$<50$ anos & 22 & 18 \\
\hline $50-70$ anos & 69 & 56.5 \\
\hline$>70$ anos & 31 & 25.4 \\
\hline \multicolumn{3}{|l|}{ UICC (clinical stage) } \\
\hline 0, I ou II & 48 & 39.3 \\
\hline III e IV & 74 & 60.7 \\
\hline \multicolumn{3}{|l|}{ Degree of differentiation } \\
\hline Poorly differentiated & 10 & 8.2 \\
\hline Moderately differentiated & 101 & 82.8 \\
\hline Well differentiated & 8 & 6.6 \\
\hline Indeterminate & 3 & 2.5 \\
\hline Total & 122 & 100 \\
\hline
\end{tabular}

CDX2 expression was found in $67.2 \%(n=82)$, beta-catenin in $42.6 \%(n=52)$ and Wnt3a in $43.4 \%(n=53)$ of the cases. The rate of inconclusive results varied between 11.5 and $15.6 \%$ (Table 2). No significant difference was found between the presence or absence of CDX2, beta-catenin and Wnt3a markers with age at diagnosis, gender, clinical stage and degree of tumor differentiation. 
TABLE 2 - Results found in immunostaining

\begin{tabular}{|l|l|c|c|}
\hline \multicolumn{1}{|c|}{ Marker } & & $\mathbf{n}$ & $\%$ \\
\hline \multirow{3}{*}{ CDX2 } & negative & 25 & 20.5 \\
& positive & 82 & 67.2 \\
\hline \multirow{2}{*}{ Beta-catenin } & inconclusive & 15 & 12.3 \\
& negative & 56 & 45.9 \\
\hline \multirow{2}{*}{ WNT3a } & positive & 52 & 42.6 \\
& inconclusive & 14 & 11.5 \\
\hline Total & negative & 50 & 41 \\
\hline
\end{tabular}

An analysis was performed to verify which factors could be related to the presence of progression (Table 3). There was no significant difference regarding the presence or absence of labeling for CDX2, beta-catenin and Wnt3a and the occurrence of disease progression. There were also no statistical differences between age at diagnosis, clinical stage at diagnosis and gender with or without the occurrence of disease progression.

TABLE 3 - Analysis of variables in relation to the presence of disease progression

\begin{tabular}{|c|c|c|c|c|c|c|}
\hline Variable & Classification & $\mathrm{n}$ & $\begin{array}{c}\% \text { of } \\
\text { cases with } \\
\text { progression }\end{array}$ & $\mathrm{p}^{*}$ & SHR & Cl 95\% \\
\hline \multirow{3}{*}{$\begin{array}{l}\text { Age at } \\
\text { diagnosis }\end{array}$} & $<50$ (ref) & 22 & $10(45.5)$ & & & \\
\hline & 50 a 70 & 69 & $25(36.2)$ & 0.225 & 0.64 & $0.31-1.31$ \\
\hline & $>70$ & 31 & $8(25.8)$ & 0.143 & 0.49 & $0.20-1.27$ \\
\hline \multirow{2}{*}{ Gender } & Fem (ref) & 59 & $16(27.1)$ & & & \\
\hline & Male & 63 & 27 (42.9) & 0.127 & 1.63 & $0.87-3.0$ \\
\hline \multirow{3}{*}{$\begin{array}{l}\text { Degree of } \\
\text { differentiation } \\
\text { (excluded } \\
\text { "indet") }\end{array}$} & $\begin{array}{l}\text { Poorly } \\
\text { differentiated (0) }\end{array}$ & 10 & $1(10.0)$ & & & \\
\hline & $\begin{array}{l}\text { Well differentiated } \\
\text { (ref) (2) }\end{array}$ & 8 & $3(37.5)$ & 0.241 & 3.46 & $0.44-27.5$ \\
\hline & Moderate (1) & 101 & 39 (38.6) & 0.360 & 2.90 & $0.30-28$ \\
\hline \multirow{2}{*}{ UICC } & O/I/II & 48 & $15(31.2)$ & & & \\
\hline & III/IV & 74 & $28(37.8)$ & 0.085 & 1.68 & $0.93-3.05$ \\
\hline \multirow{3}{*}{ CDX2 } & Negative (ref) & 25 & $9(36.0)$ & & & \\
\hline & Positive & 82 & $28(34.1)$ & 0.982 & 0.99 & $0.47-2.08$ \\
\hline & Inconclusive & 15 & $6(40.0)$ & 0.489 & 1.46 & $0.50-4.2$ \\
\hline \multirow{3}{*}{ Beta-catenin } & Negative (ref) & 56 & $18(32.1)$ & & & \\
\hline & Positive & 52 & $21(40.4)$ & 0.610 & 1.18 & $0.63-2.20$ \\
\hline & Inconclusive & 14 & $4(28.6)$ & 0.902 & 1.08 & $0.34-3.43$ \\
\hline \multirow{3}{*}{ Wnt3 } & Negative (ref) & 50 & $20(40.0)$ & & & \\
\hline & Positive & 53 & $17(32.1)$ & 0.094 & 0.58 & $0.30-1.10$ \\
\hline & Inconclusive & 19 & $6(31.6)$ & 0.364 & 0.66 & $0.25-1.63$ \\
\hline
\end{tabular}

SHR=subdistribution hazard ratio; $\mathrm{Cl} 95 \%$ : 95\% confidence interval

Regarding the evolution to death, no significant difference was found between the presence or absence of the studied markers and the occurrence of such an outcome. A statistically significant difference was found when assessing the degree of tumor differentiation, staging at diagnosis and the presence of disease progression. The death event was more commonly found in poorly differentiated tumors (HR 17.6; 3.5-88.6), in the more advanced stages (HR 2.52; 1.49-4.25) and in patients who presented progression of disease (HR 5.91; 3.37-10.4, Table 4).
TABLE 4 - Analysis of variables in relation to the death event

\begin{tabular}{|c|c|c|c|c|c|c|}
\hline Variable & Classification & $\mathrm{n}$ & $\%$ death & $\mathrm{p}^{*}$ & HR & $\mathrm{Cl} 95 \%$ \\
\hline \multirow{3}{*}{$\begin{array}{l}\text { Age at } \\
\text { diagnosis }\end{array}$} & $<50$ (ref) & 22 & 9 (40.9\%) & & & \\
\hline & 50 a 70 & 69 & 42 (60.9\%) & 0.361 & 1.40 & $0.68-2.88$ \\
\hline & $>70$ & 31 & 17 (54.8\%) & 0.099 & 1.98 & $0.88-4.45$ \\
\hline \multirow{2}{*}{ Genre } & Male (ref) & 63 & 32 (50.8\%) & & & \\
\hline & Fem & 59 & 36 (61.0\%) & 0.134 & 1.44 & $0.89-2.34$ \\
\hline \multirow{3}{*}{$\begin{array}{l}\text { Degree of } \\
\text { differentiation } \\
\text { (excluded } \\
\text { "indet") }\end{array}$} & $\begin{array}{l}\text { Well diff } \\
\text { (ref) (2) }\end{array}$ & 8 & 2 (25.0\%) & & & \\
\hline & Moderate (1) & 101 & 58 57.4\%) & 0.078 & 3.55 & $0.87-14.6$ \\
\hline & $\begin{array}{l}\text { Poorly } \\
\text { differentiated (0) }\end{array}$ & 10 & 7 (70.0\%) & 0.001 & 17.6 & $3.5-88.6$ \\
\hline \multirow{2}{*}{$\begin{array}{l}\text { UICC } \\
\text { (grouped) }\end{array}$} & O/I/II & 48 & 22 (45.8\%) & & & \\
\hline & III/IV & 74 & 46 & $<0.001$ & 2.52 & $1.49-4.25$ \\
\hline \multirow{2}{*}{$\begin{array}{l}\text { Progression } \\
\text { event }\end{array}$} & No & 79 & 41 (51.9) & & & \\
\hline & Yes & 43 & $27(62.8)$ & $<0.001$ & 5.91 & $3.37-10.4$ \\
\hline \multirow{3}{*}{ CDX2 } & Negat & 25 & 9 (36.0\%) & & & \\
\hline & Posit & 82 & 28 (34.1\%) & 0.373 & 1.33 & $0.71-2.51$ \\
\hline & Inconclusive & 15 & $6(40.0 \%)$ & 0.855 & 1.10 & $0.41-2.94$ \\
\hline \multirow{3}{*}{$\begin{array}{l}\text { Beta- } \\
\text { catenin }\end{array}$} & Negative (ref) & 56 & 28 (50.0\%) & & & \\
\hline & Positi & 52 & 35 (67.3\%) & 0.480 & 1.20 & $0.73-1.97$ \\
\hline & Inconclusi & 14 & 5 (35.7\%) & 0.791 & 0.88 & $0.34-2.28$ \\
\hline \multirow{3}{*}{ Wnt3 } & Negative (ref) & 50 & 30 (60.0\%) & & & \\
\hline & rusilive & 53 & 30 (56.6\%) & 0.204 & 0.72 & $0.43-1.20$ \\
\hline & Inconclusive & 19 & 8 (42.1\%) & 0.268 & 0.64 & $0.29-1.40$ \\
\hline
\end{tabular}

* COX regression model and Wald test, $\mathrm{p}<0.05$

\section{DISCUSSION}

In this research, the absence of CDX2 was found in $20.5 \%$ of the samples analyzed, similar to that previously described in the literature, where poor expression or absence of CDX2 was found in $5-29 \%$ of the CRC ${ }^{1,2,19}$. Similarly, Kaimaktchiev et al. found this marker overexpressed in $85.7 \%$ of their CRC samples and in $97.9 \%$ of their colorectal adenomas ${ }^{16}$.

Contrary to the findings of the present study, previous research had linked the absence of CDX2 expression with less histological differentiation and more advanced stage at diagnosis ${ }^{2,3,20}$, as well as lower disease-free and progressionfree survival rates $3,8,20$. Nolte et al. demonstrated that the lower expression of CDX2 is inversely related to the probability of certain factors, such as female gender, mucinous histology, higher tumor pathological degree, higher pT staging, higher TNM classification, lower disease-free survival $(41 \%$ vs. $74 \%$ in positive CDX2 tumors) and lower overall survival in five years (33\% vs. 59\%), maintaining significance even in multivariate analyzes that excluded gender, tumor grade and clinical stage $^{20}$. In this study, no relationship was found between the absence of CDX2 and a significant increase in risk for outcomes such as disease progression, death and progression in clinical staging or degree of tumor differentiation.

The expression of Wnt3a in the present study, in $43.4 \%$ of the evaluated samples, was noticeably lower than that described by Qi et al., where 172 (88.2\%) of 203 CRC samples demonstrated positive expression of Wnt3a, and the cases with strong expression were related to less differentiated tumors, advanced clinical stage, presence of metastasis and with tumor recurrence ${ }^{22}$. A reduction in overall survival was noted according to the expression of Wnt3a, being 76.4 months for patients without expression of this marker and 41.7 months for those who had strong expression in tumor 
cells. There was no significant difference in the expression of Wnt3a when assessing patient age, gender or tumor size ${ }^{22}$.

The study by Madison et al. found Wnt3a expressed in $89.9 \%$ of CRC cases (weak in $44.7 \%$ and strong in $45.2 \%$ ), and a relationship between positivity for Wnt3a with the presence of vasculogenic mimicry. The presence of it was associated with poorly differentiated tumors ( $56.6 \%$ vs. $7.1 \%$ in well-differentiated tumors), advanced clinical stage (58.3\% in EC IV vs. $0 \%$ in EC I) and the presence of metastasis or recurrence $(31.2 \%$ vs. $10.7 \%$ when there is no metastasis or recurrence). The researchers found no significant difference in the expression of Wnt3a in relation to gender and age, as well as in relation to the degree of tumor differentiation, disease progression, evolution to death or clinical staging at diagnosis. Considering that there is no guide for reading the immunostaining, some samples that were considered weakly positive may have been considered negative.

Nuclear beta-catenin expression was observed in $42.6 \%$ of the samples, similar to that found by Morikawa et al, where the positivity of this marker was recorded in $323(47 \%)$ of 724 cases of $C R C^{18}$. Since mutations in the Wnt/beta-catenin pathway are often associated with the development of cancer - but beta-catenin expression is only found in less than half of the tumors - it is thought that there are other mechanisms that demonstrate the activation of this gene pathway ${ }^{25}$.

The present study demonstrated important differences in relation to the recent literature, mainly in relation to the prognosis, since no marker was found among those studied that can be used as an indication of probability for disease progression or evolution to death. This can be explained by possible differences between studies in the interpretation of the samples, since there are no single criteria that standardize the reading of the expression of biomarkers in immunoanalysis.

\section{CONCLUSION}

The tumor markers CDX2, beta-catenin and Wnt3a were not good instruments to assess the chance of disease progression or the possibility of evolution to death in the context of colorectal cancer.

\section{REFERENCES}

1. Baba Y, Nosho K, Shima K, Freed E, Irahara N, Philips J et al. Relationship of CDX2 loss with molecular features and prognosis in colorectal cancer. Clinical cancer research : an official journal of the American Association for Cancer Research. 2009; 15(14): 4665-4673. doi:10.1158/1078-0432. CCR-09-0401

2. Bae JM, Lee TH, Cho NY, Kim TY, Kang GH. Loss of CDX2 expression is associated with poorprognosisincolorectal cancerpatients. World Journal ofGastroenterology.2015;21(5):1457-1467.doi:10.3748/wjg.v21.i5.1457

3. BakarisS, ÇetinkayaA, EzberciF, Ekerbicer, H. Expression ofhomeodomain protein CDX2 in colorectal adenoma and adenocarcinoma. Histology and histopathology. 2008; 23: 1043-7. doi:10.14670/HH-23.1043

4. BeckF,StringerEJ.TheroleofCdxgenesinthegutandinaxialdevelopment. Biochemical Society Transactions. 2010; 38 (2): 353-357. doi: https://doi. org/10.1042/BST0380353

5. Bogaert J, Prenen H. Molecular genetics of colorectal cancer. Annals of Gastroenterology.2014;27(1):9-14.PMID:24714764;PMCID:PMC3959535.

6. Bonhomme C, Duluc I, Martin E, Chawengsaksophak K, Chenard MP, Kedinger $\mathrm{M}$ et al. The $\mathrm{Cdx} 2$ homeobox gene has a tumour suppressor function in the distal colon in addition to a homeotic role during gut development. Gut.2003;52(10):1465-1471. doi:10.1136/gut.52.10.1465
7. Cillo C, Cantile M, Faiella A, Boncinelli E. Homeobox genes in normal and malignant cells. Journal of Cellular Physiology. 2001; 188: 161-169. doi:10.1002/jcp.1115

8. Dalerba P, Sahoo D, Paik S, Guo X, Yothers G, Song N et al. CDX2 as a Prognostic Biomarker in Stage II and Stage III Colon Cancer. The New England Journal of Medicine. 2016; 374(3): 211-222. doi:10.1056/ NEJMoa1506597

9. Diger, $\mathrm{N}$ et al. Is superficial colorectal lesions with low and high grades intraepithelial neoplasms more prevalent in older above 65 years? ABCD, arq. Bras. Cir. Dig.2019, vol.32, n.4, e1478. Epub Dec 20,2019. ISSN 2317-6326. https://doi.org/10.1590/0102-672020190001e1478.

10. Freitas, Betal.Obesidadeedesenvolvimentodeadenomaestãoassociados como precursores do câncer colorretal?ABCD, arq. Bras. Cir. Dig. 2020, vol 33, n1, e1500. Epub July 08,2020. ISSN 2317-6326

11. Freire EG, Albuquerque J, Leal IP, Sousa NA, Graça J. Effect of chronic renal dysfunction on the permeability of the colon to water and electrolytes: experimental study in rats. Arquivos Brasileiros de Cirurgia Digestiva. 2019; 32(4): e1472. doi:10.1590/0102-672020190001e1472

12. Guo RJ, Funakoshi S, Lee HH, Kong J, Lynch JP. The intestine-specific transcriptionfactorCdx2 inhibits beta-catenin/TCFtranscriptionalactivity by disrupting the beta-catenin-TCF protein complex. Carcinogenesis. 2010:31(2):159-166. doi:10.1093/carcin/bgp213

13. Howlader N, Noone AM, Krapcho M, Miller D, Bishop K, Kosary CL, et. al. SEER Cancer Statistics Review, 1975-2014, National Cancer Institute. Bethesda, MD, based on November 2016 SEER data submission, posted to the SEER web site, April 2017 [acesso em 2017 mar]. Disponível em: https://seer.cancer.gov/csr/1975_2014/

14. Instituto Nacional de Câncer. Incidência de câncer no Brasil [base de dados na Internet]. Rio de Janeiro. Instituto Nacional de Câncer; 2019, [acessoem2020fev].Disponívelem:https://www.inca.gov.br/estimativa/ introducao

15. Instituto Nacional de Câncer. Incidência de câncer no Brasil [base de dados na Internet]. Rio de Janeiro. Instituto Nacional de Câncer; 2020, [acessoem2020mar].Disponívelem:https://www.inca.gov.br/estimativa/ sintese-de-resultados-e-comentarios

16. Kaimaktchiev V, Terracciano L, Tornillo L, Spichtin H, Stoios D, Bundi M et al. The homeobox intestinal differentiation factor CDX2 is selectively expressed ingastrointestinaladenocarcinomas. ModernPathology.2004 17: 1392-1399. https://doi.org/10.1038/modpathol.3800205

17. Madison BB, Braunstein K, Kuizon E, Portman K, Qiao XT, Gumucio DL. Epithelial hedgehog signals pattern the intestinal crypt-villus axis. Development. 2005;132(2): 279-289. doi: 10.1242/dev.01576

18. Morikawa T, Baba Y, Yamauchi M, Kuchiba A, Nosho K, Shima K, et al. STAT3 expression, molecular features, inflammation patterns, and prognosis in a database of 724 colorectal cancers. Clinical Cancer Research: an official journal of the American Association for Cancer Research. 2011;17(6):1452-1462. doi:10.1158/1078-0432.CCR-10-2694

19. Moskaluk C, Zhang H, Powell S, Cerilli LA, Hampton GM, Frierson HF. Cdx2 Protein Expression in Normal and Malignant Human Tissues: An Immunohistochemical Survey Using Tissue Microarrays. Modern Pathology.2003;16:913-919. doi:10.1097/01.MP.0000086073.92773.55

20. Nolte $S$, Zlobec I, Lugli A, et al. Construction and analysis of tissue microarrays in the era of digital pathology: a pilot study targeting CDX1 and CDX2 in a colon cancer cohort of 612 patients. The Journa of Pathology: Clinical Research. 2017;3(1):58-70. doi:10.1002/cjp2.62

21. QiL, SongW, LiuZ,ZhaoX, CaoW, SunB.Wnt3aPromotesthe Vasculogenic Mimicry Formation of Colon Cancer via Wnt/ $\beta$-Catenin Signaling. Interational Journal of Molecular Sciences. 2015;16(8):18564-18579. doi:10.3390/ijms160818564

22. Qi L, Sun B, Liu Z, Cheng R, Li Y, Zhao X. Wnt3a expression is associated with epithelial-mesenchymal transition and promotes colon cancer progression. Journal of experimental \& Clinical Cancer Research: CR. 2014:33:107. doi:101186/PREACCEPT-1203114799135709.

23. Souza GD, Souza LRQ, Cuenca RM, Vilela VM, Santos BEM, Aguiar FS. Pre-and postoperative imaging methods in colorectal cancer. Arquivos Brasileiros de Cirurgia Digestiva. 2018; 31(2): e1371. doi:10.1590/0102$672020180001 \mathrm{e} 1371$.

24. Torre LA., Bray F, Siegel RL., Ferlay J, Lortet-Tieulent J, Jemal A. (2015) Global cancer statistics, 2012. CA: A Cancer Journal for Clinicians, 65: 87-108. doi:10.3322/caac.21262

25. Zhan T, Rindtorff N, Boutros M. Wnt signaling in cancer. Oncogene. 2017;36(11):1461-1473. doi:10.1038/onc.2016.304 